\title{
Solitary Intramedullary Spinal Cord Metastasis from Colon Carcinoma: A Case Report and Literature Review
}

\author{
Pierpaolo Lunardi ${ }^{1}$, Rodolfo Corinaldesi ${ }^{1}$, Tommaso Lunardi ${ }^{2}$, Roberto Floris ${ }^{2}$ \\ ${ }^{1}$ University of Perugia, Perugia, Italy \\ ${ }^{2}$ University of Rome Tor Vergata, Roma, Italy \\ Email: pierpaolo.lunardi@unipg.it
}

Received December 7, 2013; revised January 7, 2014; accepted January 14, 2014

Copyright (c) 2014 Pierpaolo Lunardi et al. This is an open access article distributed under the Creative Commons Attribution License, which permits unrestricted use, distribution, and reproduction in any medium, provided the original work is properly cited. In accordance of the Creative Commons Attribution License all Copyrights (C) 2014 are reserved for SCIRP and the owner of the intellectual property Pierpaolo Lunardi et al. All Copyright (C) 2014 are guarded by law and by SCIRP as a guardian.

\section{ABSTRACT}

It is extremely rare for cancer to present as an intramedullary spinal cord metastasis. The authors report on a case of a 74-year-old woman presenting with progressive tetraparesis to metastatic colon adenocarcinoma in the spinal cord. A review of the literature reveals that intramedullary localization is associated with a very short life expectancy, with a median survival of 3 - 4 months from the time of the diagnosis; nevertheless microsurgical removal of tumor can improve quality of life.

\section{KEYWORDS}

\section{Spinal Cord Metastasis}

\section{Introduction}

Intramedullary spinal cord metastasis (ISCMs) is an unusual complication of the cancer, representing $8.5 \%$ of CNS metastasis [1].

Spinal colorectal carcinoma related metastasis is extremely rare with only few cases reported in the literature so far. We report on a patient with an intramedullary metastasis from colon carcinoma. Total resection of the tumor has improved the quality of life of the patient. The aim of our paper is to emphasize the role of surgery, when there is an indication for improving the quality of life in patients with a very short life expectancy.

\section{Case Report}

A 74-year-old woman had undergone colectomy, without adjuvant chemotherapy for adenocarcinoma 1 year previously. Two months before admission she developed progressive weakness of her left leg and urinary hesitancy, she also noted oppressive burning and dysesthetic pain in the neck radiating in to both arms, and back pain that persist in recumbency.

Over 3 - 4 days the patient reported progressive right lower limb weakness and a severe deterioration in the left leg, that makes impossible standing, also referred progressive weakness in the upper limbs.

Neurological findings included spastic tetraparesis with severe paresis on the left leg (2/5), the right leg had a marked weakness (3/5), in the arms she had slight bilateral weakness (4/5), hyperactive tendon reflex more prominent on the left than on the right, bilateral Babinski sign, and hypoesthesia to vibration on the left hemibody and for pinprick and temperature on the right hemibody below T1. Urinary retention and reduced anal sphincter tone were also noted.

MRI images of the spine in toto showed a solitary intramedullary lesion at $\mathrm{C} 7$ level, the lesion measured about $1.5 \mathrm{~cm}$ in cranio-caudal dimension, occupying almost the entire spinal cord (Figure 1(a)).

The lesion appeared slightly hypointense on T1-w image, and hyperintense on T2-w image associated with a large proximal and distal edema extending from $\mathrm{C} 3$ to $\mathrm{T} 3$ vertebral body (Figure 1(b)), contrast-enhanced T1-w image demonstrated homogeneous enhancement and the cord appeared expanded at the same level (Figure 1(c)).

A preoperative chest radiograph showed no abnormalities, and MRI of the brain was negative for other lesions. Cerebrospinal fluid (CSF) analysis showed an elevated 

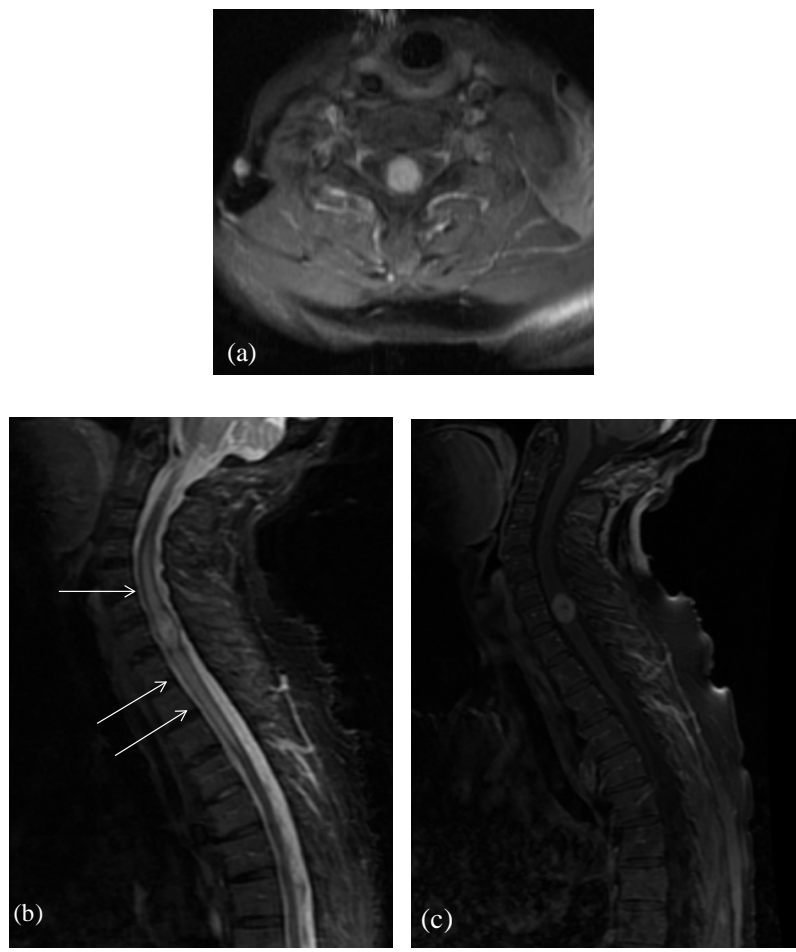

Figure 1. (a) Axial MRI T1-w post-gadolinium showing ISCM occupying almost the entire spinal cord; (b) Sagittal MRI T2-w image showing a large proximal and distal edema extending from C3 to T3 vertebral body; (c) Sagittal MRI contrast enhanced T1-w image showing a solitary mass in the intramedullary cervical spinal cord, at C7 level, with homogeneous enhancement and expanded spinal cord at the same level.

protein level, but cytology was negative. Based on the progressive neurological worsening, surgical treatment was performed.

The patient underwent C6-T1 laminectomy and the dural sac exposed was opened at the midline. Once exposed, the spinal cord appeared expanded.

A median posterior myelotomy was performed and disclosed the lesion as light yellow-reddish in color with a pseudocapsule distinguishing it from surrounding spinal cord parenchyma. It was sharply dissected out and totally removed.

The histological examination showed the pathological features of adenocarcinoma metastasizing from colon cancer. No radiotherapy was planned because adenocarcinoma is unlikely to be radiosensitive.

Postoperatively, the patient progressively showed improvement in neurological function. For both arms, the muscle strength rose to 5/5; the muscle strength of the right lower limb improved up to 4/5. However, the severe paresis on the left leg did not improve and her sphinterical disturbance and urinary hesitancy were only slightly improved. After 14 months, the patients died of local recurrence of the colon carcinoma, with invasion of sigmoid colon, uterus and bladder.

\section{Discussion}

ISCM is a rare clinical entity, comprising 1\% - 3\% of all intramedullary spinal cord tumors and accounting for only $0.1 \%-0.4 \%$ of all cancer patients $[2,3]$.

Furthermore, they account for $3 \%-5 \%$ of cases of myelopathy in patients affected by cancer [4]. Most of ISCM patients have brain metastasis and systemic metastasis at the time of the diagnosis [5]. ISCM occurs in as few as $2 \%$ of cancer autopsy; on the other hand, brain metastasis is found in $20 \%$ of cases [2,6]. The lower incidence of ISCMs can be attributed only partially to the fact that the spinal cord is frequently omitted from routine autopsies [7].

Several theories have been postulated to explain the discrepancy between the frequencies of brain and intramedullary metastasis. Arterial seeding is believed to be the most common mechanism of intramedullary metastasis. Indeed, the brain receives about one-third of the cardiac output through large vessels under high pressure, while the spinal cord receives its arterial supply from small vessels under low pressure $[8,9]$. Moreover, the medullary arteries branch off the aorta at the right angles, while the cerebral arteries are almost a direct extension of the aorta, thus favoring embolic seeding [10]. Metastasis spreading may also occur through direct extension along the nerve roots, perineural sheaths and via CSF pathways $[11,20]$.

The most common origin of the ISCMs is lung cancer, especially small cell carcinoma followed, by breast cancer, melanoma, lymphoma, and renal cell carcinoma [5, $7,12]$. ISCM from colorectal adenocarcinoma is extremely rare, with only few cases reported in the literature so far $[4,8,11,13-20]$.

Table 1 summarizes the principal findings of these cases. ISCMs most commonly occur in the setting of advanced disease, but may exceptionally account for the initial presentation $[4,5]$. Pain and weakness were more common early in the course of disease, with sensory loss reported somewhat later. Bowel and bladder dysfunction most typically presented late [5]. Pseudo-Brown-Séquard or Brown-Séquard syndrome occurs in 30\% - 45\% of patients with ISCM, with progression to a cord transection syndrome $[3,7,12,16]$.

An exact diagnosis of an ISCM can be difficult even when the primary tumor is known, because clinical findings do not help to distinguish ISCM from other spinal cord lesions or non compressive myelopathies that can occur in cancer patients [4].

The differential diagnosis should include primary intramedullary tumor, spinal epidural metastasis (SEM), radiation myelopathy, paraneoplastic necrotizing myelopa- 
Table 1. Review of cases reports of patients with ISCM from colon carcinoma.

\begin{tabular}{|c|c|c|c|c|c|c|c|c|}
\hline Author & Year & $\begin{array}{l}\text { Sex \& } \\
\text { Age }\end{array}$ & Level & Symptoms & $\begin{array}{c}\text { Time } \\
\text { interval }\end{array}$ & $\begin{array}{c}\text { Other } \\
\text { Metastasis }\end{array}$ & Surgery & Outcome \\
\hline $\begin{array}{l}\text { Sansoy } \\
\text { et al. }{ }^{13}\end{array}$ & 1955 & $\mathrm{~F}, 65$ & $\mathrm{~T} 4$ & Right lower limb monoparesis & NS & No & No & NS \\
\hline $\begin{array}{c}\text { Silva \& } \\
\text { McSwain }\end{array}$ & 1967 & F, 55 & C5 - C6 & $\begin{array}{l}\text { Left neck-arm pain followed by weakness of } \\
\text { lower limbs }\end{array}$ & 15 months & Lung & Yes & $\begin{array}{l}\text { Died } 15 \text { days } \\
\text { postoperatively }\end{array}$ \\
\hline $\begin{array}{l}\text { Walker } \\
\text { et al. }\end{array}$ & 1967 & M, 56 & L1 - L2 & NS & NS & Lung & No & NS \\
\hline \multirow[t]{2}{*}{$\begin{array}{l}\text { Jellinger } \\
\text { et al. }\end{array}$} & 1979 & M, 77 & $\mathrm{~T} 11-\mathrm{L} 1$ & $\begin{array}{l}\text { Bilateral hip and leg pain with overnight } \\
\text { paraplegia }\end{array}$ & 5 years & Brain, Lung & No & $\begin{array}{l}\text { Died } 3 \text { weeks after } \\
\text { admission }\end{array}$ \\
\hline & & $\mathrm{F}, 74$ & $\mathrm{C} 2-\mathrm{C} 4$ & $\begin{array}{l}\text { Neck pain followed by lower limb weakness, } \\
\text { urinary hesitancy }\end{array}$ & 6 years & Brain & No & $\begin{array}{l}\text { Died } 9 \text { days after } \\
\text { admission }\end{array}$ \\
\hline $\begin{array}{l}\text { Foster } \\
\text { et al. }\end{array}$ & 1987 & M, 66 & C4 & $\begin{array}{l}\text { Right lower limb monoparesis and right } \\
\text { upper hyperesthesia }\end{array}$ & 4 years & NS & Yes & $\begin{array}{l}\text { Died } 2 \text { months } \\
\text { postoperatively }\end{array}$ \\
\hline \multirow[t]{2}{*}{$\begin{array}{l}\text { Schiff \& } \\
\text { O’Neil }^{12}\end{array}$} & 1996 & NS & NS & NS & NS & NS & NS & NS \\
\hline & & NS & NS & NS & NS & NS & NS & NS \\
\hline $\begin{array}{l}\text { Ogino } \\
\text { et al. }\end{array}$ & 2001 & M, 69 & C5 - C6 & $\begin{array}{l}\text { Right hemiparesis, hypalgesia below left L1 } \\
\text { level, constipation, urinary hesitancy }\end{array}$ & 4 months & Lung & Yes & $\begin{array}{l}\text { Died } 3 \text { months } \\
\text { postoperatively }\end{array}$ \\
\hline $\begin{array}{l}\text { Yano } \\
\text { et al. }{ }^{17}\end{array}$ & 2002 & NS & Thoracic & NS & NS & No & Yes & NS \\
\hline $\begin{array}{l}\text { Kaya } \\
\text { et al. }\end{array}$ & 2003 & F, 44 & T6 & Lower limbs weakness, over 1 day paraplegia & 2 years & $\begin{array}{l}\text { Brain, } \\
\text { Mediastinum }\end{array}$ & Yes & $\begin{array}{l}\text { Died } 14 \text { months } \\
\text { postoperatively }\end{array}$ \\
\hline $\begin{array}{l}\text { Grasso } \\
\text { et al. }{ }^{4}\end{array}$ & 2007 & F, 61 & C3 - C4 & $\begin{array}{l}\text { Right hemibody numbness lower limbs and } \\
\text { upper limbs weakness }\end{array}$ & NS & No & Yes & $\begin{array}{l}\text { Died } 2 \text { months } \\
\text { postoperatively }\end{array}$ \\
\hline $\begin{array}{l}\text { Kaballo } \\
\text { et al. }\end{array}$ & 2011 & M, 71 & $\mathrm{C} 2-\mathrm{C} 3$ & $\begin{array}{l}\text { Right upper limb and lower limb feel pins and } \\
\text { needles; over } 5 \text { days developed } \\
\text { Brown-Séquard syndrome }\end{array}$ & 16 months & Liver, Lung & No & NS \\
\hline Present case & 2012 & F, 74 & $\mathrm{C} 7$ & $\begin{array}{l}\text { Left lower limb weakness, urinary hesitancy, } \\
\text { pain during recumbancy; over } 3 \text { - } 4 \text { days } \\
\text { severe tetraparesis }\end{array}$ & 1 years & No & Yes & $\begin{array}{l}\text { Died } 14 \text { months } \\
\text { postoperatively }\end{array}$ \\
\hline
\end{tabular}

NS: not specified; Time interval: interval between colon surgery and onset of spinal symptoms; Symptoms: symptoms at onset.

thy, vascular malformations, syringomyelia, demyelinating plaques and meningeal carcinomatosis [11,18].

The most important factors to consider in diagnosis are time of clinical course, pain, and CSF cytology [4]. The rapid progression of symptoms less than 1 month distinguishes ISCM from primary intramedullary tumors such as gliomas, which typically present with a slower progression of symptoms [5,7,11]. Muscle atrophy and fasciculation commonly accompany the long-standing muscle weakness reported to accompany primary intramedullary tumors, whereas muscle atrophy has rarely been reported metastatic intramedullary disease [16].

ISCMs are much less common than metastatic epidural disease, which involves the dura in $10 \%$ of all cancer patients [5]. Both SEM and ISCM can occur with pain, and can be complicated by rapid deterioration in neurologic status. In ISCM pain tends to be a little less ubiquitous and severe characterized by a strong asymmetry of myelopathy. This is seen in almost half of patients with ISCM and only 3\% of patients with SEM [21].

The clinical pictures of radiation myelopathy and necrotizing myelopathy are usually that of a painless he- micord syndrome [22]. Neoplastic meningitis is usually suspected on the basis of multifocal neurologic deficits, including cranial nerve palsies and spinal root deficit. Signs and symptoms of increased intracranial pressure are frequently observed secondary to obstruction of CSF pathway. CSF analysis reveals pleocytosis and malignant cells in the majority of patients with leptomeningeal disease [7].

CSF findings in ISCM are usually negative or show only an increase in protein and a mild pleocytosis. If positive, meningeal involvement may have occurred [4].

However when a spinal lesion is suspected in a patient with a history of malignancy, MRI with gadolinium enhancement is mandatory.PET has a sensitivity of $96 \%$ in detecting spinal metastasis, and this is even more sensitive when combined with CT scan [19].

The prognosis of a patient who has an intramedullary spinal cord lesion is grave. Intramedullary localization is associated with a very short life expectancy with a median survival of 3 - 4 months from the time of the diagnosis $[7,11]$. Death is due to complications of neurologic damage and progressive systemic cancer. 
The management of ISCM remains controversial since the recurrent recommendations are based on anecdotal experiences described on retrospective reports [4]. The standard therapy is radiation treatment, with or without steroids $[7,11,23]$.

Modern radiotherapy techniques, such as intensity-modulated radiation therapy, cyberknife, and tomotherapy can hold promise in efficacy; however, so far, no considerable data support their use [4]. It must be noted, however, that only radiosensitive metastasis, such as small cell carcinoma, breast cancer, or lymphoma respond to radiation therapy.

Several factors are important when considering surgical treatment such as patient's age, physical condition, location, and severity of the primary neoplasm, as well as other metastasis, and surgical risk [4]. To date, in selected cases, the prognosis may be improved by early diagnosis and surgical removal using microsurgical techniques.

Like intracranial metastasis, ISCMs are often discrete, well-circumscribed deposits and subject to gross total resection.

One should consider microsurgical resection of ISCMs in patients with well-controlled radioresistant primary tumors a discrete, solitary, intramedullary metastasis, without leptomeningeal involvement [16]. In these cases, microsurgical removal of ISCM can improve the quality of life.

\section{REFERENCES}

[1] S. S. Lee, M. K. Kim, S. J. Sym, et al., "Intramedullary Spinal Cord Metastases: A Single-Institution Experience," Journal of Neurooncology, Vol. 84, No. 1, 2007, pp. 8589. http://dx.doi.org/10.1007/s11060-007-9345-z

[2] D. A. Costigan and M. D. Winkelman, "Intramedullary Spinal Cord Metastasis. A Clinicopathological Study of 13 Cases," Journal of Neurooncology, Vol. 62, No. 2, 1985, pp. 227-233.

[3] J. W. Dunne, C. G. Harper and R. Pamphlett, "Intramedullary Spinal Cord Metastases: A Clinical and Pathological Study of Nine Cases,” Quarterly Journal of Medicine, Vol. 61, No. 235, 1986, pp. 1003-1020.

[4] G. Grasso, F. Meli, R. Patti, et al., "Intramedullary Spinal Cord Tumor Presenting as the Initial Manifestation of Metastatic Colon Cancer: Case Report and Review of the Literature,” Spinal Cord, Vol. 45, No. 12, 2007, pp. 793796. http://dx.doi.org/10.1038/sj.sc.3102105

[5] E. S. Connolly Jr., C. J. Winfree, P. C. McCormick, et al., "Intramedullary Spinal Cord Metastasis: Report of Three Cases and Review of the Literature," Surgical Neurology, Vol. 46, No. 4, 1996, pp. 329-337. http://dx.doi.org/10.1016/S0090-3019(96)00162-0

[6] J. L. Chason, F. B. Walker and J. W. Landers, "Metastatic Carcinoma in the Central Nervous System and Dorsal Root Ganglia. A Prospective Autopsy Study,” Cancer, Vol. 16,
No. 6, 1963, pp. 781-787.

[7] J. L. Grem, J. Burgess and D. L. Trump, “Clinical Features and Natural History of Intramedullary Spinal Cord Metastasis," Cancer, Vol. 56, No. 9, 1985, pp. 2305-2314. http://dx.doi.org/10.1002/1097-0142(19851101)56:9<230 5::AID-CNCR2820560928>3.0.CO;2-X

[8] Y. J. Silva and B. McSwain, "Intramedullary Spinal Cord Metastasis: The Sole Clinical Manifestation of an Adenocarcinoma of the Colon," Canadian Journal of Surgery, Vol. 10, No. 3, 1967, pp. 341-344.

[9] R. N. Edelson, M. D. Deck and J. B. Posner, "Intramedullary Spinal Cord Metastases. Clinical and Radiographic Findings in Nine Cases,” Neurology, Vol. 22, No. 12, 1972, pp. 1222-1231. http://dx.doi.org/10.1212/WNL.22.12.1222

[10] B. Tanghetti, G. L. Fumagalli, F. Giunta, et al., "Intramedullary Spinal Cord Metastases,” Journal of Neurosurgical Science, Vol. 27, No. 2, 1983, pp. 117-124.

[11] K. Jellinger, P. Kothbauer, E. Sunder-Plassmann, et al., "Intramedullary Spinal Cord Metastases,” Journal of Neurooncology, Vol. 220, No. 1, 1979, pp. 31-41.

[12] D. Schiff and B. P. O’Neill, "Intramedullary Spinal Cord Metastases: Clinical Features and Treatment Outcome,” Neurology, Vol. 47, No. 4, 1996, pp. 906-912. http://dx.doi.org/10.1212/WNL.47.4.906

[13] O. M. Sansoy, "Intramedullary Spinal Cord Metastasis from Carcinoma of the Colon Simulating Acute Ascending Myelitis," Mossori Medicine, Vol. 52, No. 11, 1955, pp. 864-866.

[14] L. G. Walker Jr., "Intramedullary Spinal Cord Metastasis from Carcinoma of the Colon,” Ambulatory Surgery, Vol. 33, No. 5, 1967, pp. 422-424.

[15] O. Foster, H. A. Crockard and M. P. Powell, "Syrinx Associated with Intramedullary Metastasis," Journal of Neurology, Neurosurgery \& Psychiatry, Vol. 50, No. 8, 1987, pp. 1067-1070. http://dx.doi.org/10.1136/jnnp.50.8.1067

[16] M. Ogino, R. Ueda, M. Nakatsukasa and I. Murase, "Successful Removal of Solitary Intramedullary Spinal Cord Metastasis from Colon Cancer," Clinical Neurology and Neurosurgery, Vol. 104, No. 2, 2002, pp. 152-156. http://dx.doi.org/10.1016/S0303-8467(02)00004-5

[17] S. Yano, K. Hida, T. Seki, et al., "Intramedullary Spinal Cord Metastasis: Two Case Reports and Literature Review," No Shinkei Gek A, Vol. 30, No. 2, 2002, pp. 189196.

[18] R. A. Kaya, T. Dalkiliç, F. Ozer, et al., "Intramedullary Spinal Cord Metastasis: A Rare and Devastating Complication of Cancer-Two Case Reports," Neurologia MedicoChirurgica (Tokyo), Vol. 43, No. 12, 2003, pp. 612-615. http://dx.doi.org/10.2176/nmc.43.612

[19] M. A. Kaballo, D. D. Brennan, M. El Bassiouni, et al., "Intramedullary Spinal Cord Metastasis from Colonic Carcinoma Presenting as Brown-Séquard Syndrome: A Case Report," Journal of Medical Case Reports, Vol. 25, 2011, p. 342. http://dx.doi.org/10.1186/1752-1947-5-342

[20] T. Gasser, I. E. Sandalcioglu, B. El Hamalawi, et al., "Surgical Treatment of Intramedullary Spinal Cord Metastases of Systemic Cancer: Functional Outcome and 
Prognosis,” Journal of Neurooncology, Vol. 73, No. 2, 2005, pp. 163-168.

http://dx.doi.org/10.1007/s11060-004-4275-5

[21] M. Mut, D. Schiff and M. E. Shaffrey, "Metastasis to Nervous System: Spinal Epiduraland Intramedullary Metastases," Journal of Neurooncology, Vol. 75, No. 1, 2005, pp. 43-56. http://dx.doi.org/10.1007/s11060-004-8097-2

[22] M. D. Winkelman, D. J. Adelstein and N. L. Karlins, "Intramedullary Spinal Cord Metastasis. Diagnostic and Thera- peutic Considerations," Archives of Neurology, Vol. 44, No. 5, 1987, pp. 526-531.

http://dx.doi.org/10.1001/archneur.1987.00520170054022

[23] F. Tognetti, G. Lanzino and F. Calbucci, "Metastases of the Spinal Cord from Remote Neoplasms. Study of five cases,” Surgical Neurology, Vol. 30, No. 3, 1988, pp. 220-227.

http://dx.doi.org/10.1016/0090-3019(88)90275-3 